\title{
Effect of sodium hydroxide concentrations and particle sizes on silica extraction from mineral rock obtained in Kalirejo village, Kokap, Kulonprogo, Yogyakarta
}

\author{
Tutik Muji Setyoningrum*, Sri Wahyu Murni, Wibiana Wulan Nandari, Muhamad Maulana Azimatun Nur
}

Chemical Engineering Department, Faculty of Industrial Engineering, UPN “Veteran” Yogyakarta Jl. SWK 104 Condongcatur, Sleman, Yogyakarta

\begin{abstract}
Artikel histori :
Diterima 08 Maret 2021

Diterima dalam revisi 25 April 202

Diterima 05 Mei 2021

Online 07 Mei 2021
\end{abstract}

\begin{abstract}
Silica is mainly used in the production of rubber, glass, cement, ceramics, paper, cosmetics, electronics, paintings, healthcare and other industries. Kalirejo village has a potential abundant resource of silica minerals. However, to refine the silica, a high cost of extraction should be done to obtain high purity. Different refining methods influence the quality of silica. The purpose of this research was to study the refining process of silica obtained from Kalirejo village, Kokap, Kulonprogo by applying simple and cheap solid-liquid extraction. The extraction was done by varying the particle size of the rock at $100-200$ mesh, while $\mathrm{NaOH}$ concentration was varied at $0.5 \mathrm{~N}$ to $5 \mathrm{~N}$. Results showed that the mineral taken from Kalirejo village was dominated by silica $(23 \% \mathrm{~m} / \mathrm{m})$. The largest extract (4.89 gram) was obtained at 200 mesh and using $\mathrm{NaOH} 5 \mathrm{~N}$ with yield of $15.07 \% \mathrm{~m} / \mathrm{m}$. Higher $\mathrm{NaOH}$ and higher particle size enhanced the extraction yield. This finding could help small communities in Kalirejo village to enhance the quality of silica by employing simple and cheap extraction process.
\end{abstract}

Keywords: extraction, silica, particle size, $\mathrm{NaOH}$

\section{Introduction}

Silica is a chemical compound with the molecular formula $\mathrm{SiO}_{2}$ (silicon dioxides) which can be obtained from mineral, vegetable and crystal synthesis. Besides forming naturally, silica with a tridymite crystal structure can be obtained by heating silica at a temperature of $870^{\circ} \mathrm{C}$, while silica with a cristobalite structure can be obtained when the heating process is carried out at $1470{ }^{\circ} \mathrm{C}$ (Fernandes et al., 2017).

Several methods can be used to obtain a high grade of silica. Extraction is the most common method to enhance the purity of silica (Chun and Lee, 2020). The basic principle of extraction is by dissolving polar compounds in polar solvents and non-polar compounds in non-polar solvents. Extraction process conditions as temperature, solvent solution concentration, extraction time, and stirring are factors that greatly influence the extraction process. However, to be implemented in a small business scale, a cheap extraction process should be carried out to make it more feasible.

According to previous researcher, silica rock can be simply extracted by using $\mathrm{NaOH}$ to create a solution of sodium silicate (Ishmah, et al., 2020). The solution is mixed with $\mathrm{HCl}$ to precipitate sodium silicate. However, previous research has not included particle size of the mineral in the extraction process. Moreover, previous study reported that Kokap village, Kulonprogo, Yogyakarta, is a potential zone that contains minerals, mostly consist of silica (Rais et al., 2020). However, most of the community could not obtain a high grade of silica from the rocks due to lacking of the knowledge. We assume that by using a cheap and simple process by combining $\mathrm{NaOH}$ and particle size of the mineral, higher purity of silica can be obtained. The aim of this research was to investigate the effect of sodium hydroxide and particle sizes of mineral rock on the extraction of minerals obtained in Kalirejo Village to obtain high purity of silica. This is the first report that demonstrated the potency of minerals rock collected from Kokap village to produce silica by using simple and cheap extraction process.

\section{Materials and Methods}

\subsection{Material Preparation}

The material used in this study was obtained from Kalirejo, Kokap, Kulonprogo Village, Yogyakarta. The mineral rock was washed twice using distilled water, then it was dried overnight, The dried rock was broken down and chrushed using a crusher, then sieved using a screening with a size of 80 up to 200 mesh. The prepared sample was then chararterized by X-ray Diffraction (XRD). The main chemicals used in this experiment were $\mathrm{HCl}$ (pro analysis, Sigma Aldrich), and $\mathrm{NaOH}$ (pro analysis, Sigma Aldrich).

\subsection{Extraction}

The extraction was performed in a $1 \mathrm{~L}$ stirred three-neck reactor. Fifty gram of the sample with different particle sizes (100-200 mesh) was extracted with $\mathrm{NaOH}$ solution (100

\footnotetext{
* Corresponding Author: (0274) 486733

Email: tutikmuji@upnyk.ac.id
} 
Citasi: Setyoningrum, T.M., Murni, S.W., Nandari, W.W., Nur, M.M.A., 2021, Effect of sodium hydroxide concentrations and particle sizes on silica extraction from mineral rock obtained in Kalirejo village, Kokap, Kulonprogo, Yogyakarta. Eksergi, 18(1), 29-31

$\mathrm{mL})$ at different concentrations $(0.5-5 \mathrm{~N})$, then heated at $100-105^{\circ} \mathrm{C}$ for $60 \mathrm{~min}$, and stirred at $300 \mathrm{rpm}$. The extract was then cooled and filtered using filter paper (Whatman 40) at the end of the process.

\subsection{Silica formation and drying stage}

The filtrate was precipitated by using $\mathrm{HCl}(2 \mathrm{~N})$ until $\mathrm{pH}$ lower than 7 to obtain sodium silicate. The precipitates was filtered using filter paper (Whatman 40) and dried at $100 \mathrm{oC}$ for 4 hours. The silica formed was then weighed until a constant weight obtained.

\subsection{Analysis}

The conversion of the sample was calculated using Eq. 1.

yield $=\frac{\text { weight of silica }}{\text { weight of sample }} \times 100 \% \quad$ Eq. 1

To ensure the silica content in the product, the dried precipitate was analyzed using XRD analysis from the highest yield

\section{Result and Discussion}

\subsection{Raw Material Analysis}

The sample taken from Kalirejo, Kokap, Kulonprogo was analysed using X-RD at the National Nuclear Energy Agency, Yogyakarta. The result of the element was shown in Table 1. Figure 1 showed XRD spectra. The result was then identified using crystallography open database. It is found that the silica was found in the form of $\left(\mathrm{SiO}_{2}\right)_{\mathrm{n}}$.

From the analysis, the sample was dominated by silicate with value $23.37 \%$, followed by aluminium, and sulfur. Compared to other mineral sites, the mineral rock from Kalirejo village is almost equal compared to previous research that reported silica content from Bali and Lombok were 19 and $21 \%$, respectively (Ishmah et al., 2020).

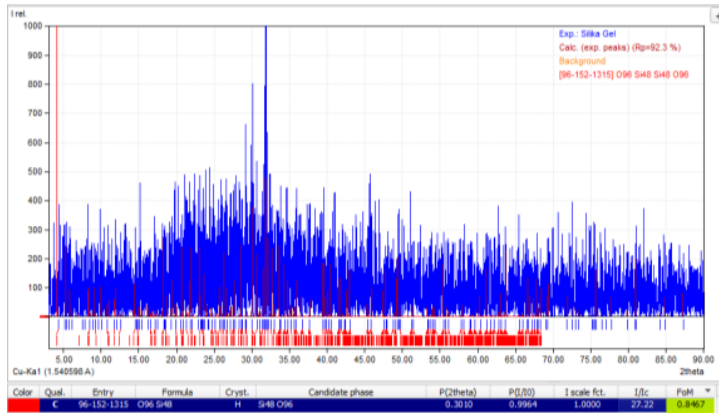

Figure 1. XRD result from mineral rocks collected from Kokap village

\subsection{Effect of $\mathrm{NaOH}$ and particle size}

Figure 2 shows the relationship between the variation in $\mathrm{NaOH}$ concentration and the weight of silica at particle sizes of 80 mesh, 100 mesh, 150 mesh and 200 mesh. The highest silica gel obtained was found in 150 and 200 mesh, with the addition of $5 \mathrm{~N} \mathrm{NaOH}$. The addition of $\mathrm{NaOH}$ from 4 to $5 \mathrm{~N}$ in 150 and 200 mesh drastically enhanced the silica gel production.

Figure 3 showed that the largest silica yield can be taken at 200 mesh size with $5 \mathrm{~N} \mathrm{NaOH}$. The amount of silica taken was 4.89 grams in the form of silica gel $\left(\mathrm{H}_{2} \mathrm{SiO}_{3}\right)$, and in the form of $\mathrm{Si}$ of 1.75 grams, where the initial silica content in mineral was 11.68 grams.

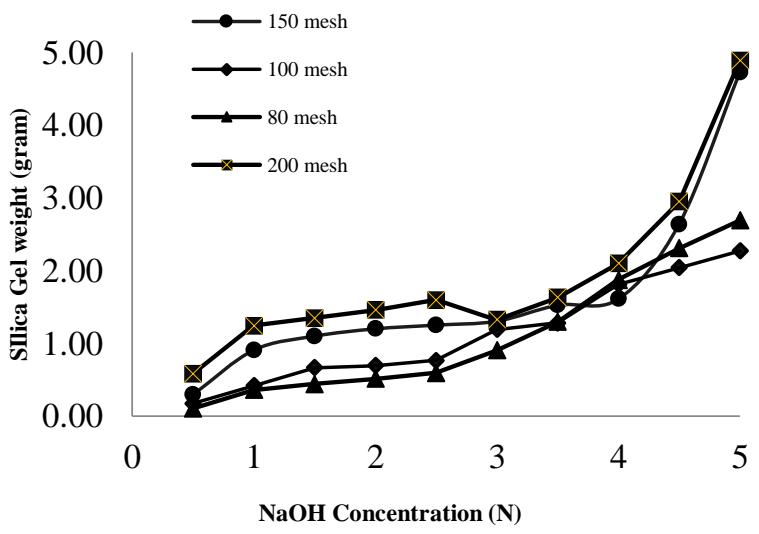

Figure 2. Interaction effect of silica gel weight and the concentration of $\mathrm{NaOH}$

In this experiment, it is found that the increasing of $\mathrm{NaOH}$ concentration increased the yield and the weight of silica produced at the same particle size. This is due to the higher $\mathrm{NaOH}$ could dissolve more silica contained in the sample. Previous study reported that the increasing $\mathrm{NaOH}$ concentration up to $3 \mathrm{~N}$ could increase the silica extracted from pumice (Sempana et al., 2018). Moreover, Zuwwana et al. (2021) found that the extraction of silica from rice husk was optimum at $3 \mathrm{~N} \mathrm{NaOH}$. $\mathrm{NaOH}$ is the most common solvent to extract silica into form of sodium silicate as mentioned earlier (Chun and Lee., 2020).

$$
\mathrm{SiO}_{2}(\mathrm{~s})+2 \mathrm{NaOH}(\mathrm{l}) \rightarrow \mathrm{Na}_{2} \mathrm{SiO}_{3}(\mathrm{l})+\mathrm{H}_{2} \mathrm{O}(\mathrm{l})
$$

Sodium silicate was then precipitated using acid.

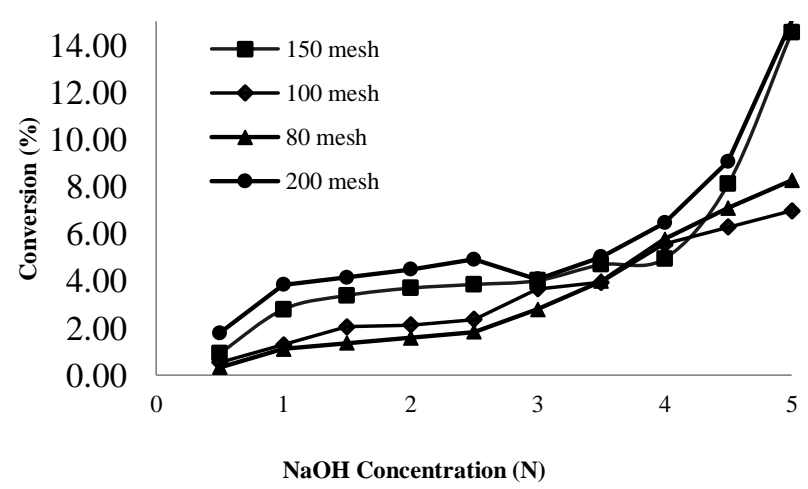

Figure 3. Effect of $\mathrm{NaOH}$ concentration on silica conversion 
Different mineral particle sizes (80 mesh, 100 mesh, 150 mesh, and 200 mesh) also influenced the yield and the weight of silica. This is due to the particle size that influence the surface area of the material, thus, increasing the extraction time. Chun and Lee (2020) reported that the effect of particle size influenced the concentration of silica extracted from rice husk ash. Previous research also demonstrated that $\mathrm{NaOH}$ could interact very stable with the higher surface area of silica (Rimsza et al., 2018). However, in this research, the yield was still small. It is necessary to study the normality of greater $\mathrm{NaOH}$ and the quality of pure $\mathrm{NaOH}$ analysis and the particle size can be varied more finely and the extraction temperature can be enlarged. Previous study reported that pure silica could be extracted from rice husks ash when high temperature $650{ }^{\circ} \mathrm{C}$ was used in the extraction process (Ilochonwu et al., 2015).

Table 1. Elemental content in the mineral sample obtained from Kokap village

\begin{tabular}{lr}
\hline Element & Composition \\
\hline $\mathrm{Si}$ & $23.37 \%$ \\
$\mathrm{Al}$ & $3.09 \%$ \\
$\mathrm{~S}$ & $2.79 \%$ \\
$\mathrm{Cl}$ & $0.14 \%$ \\
$\mathrm{~K}$ & $2.92 \%$ \\
$\mathrm{Ca}$ & $1.12 \%$ \\
$\mathrm{Ti}$ & $0.38 \%$ \\
$\mathrm{Fe}$ & $7.26 \%$ \\
$\mathrm{As}$ & $0.29 \%$ \\
$\mathrm{Mn}$ & $0.042 \%$ \\
$\mathrm{Cu}$ & $0.003 \%$ \\
$\mathrm{Zn}$ & $0.028 \%$ \\
$\mathrm{Ga}$ & $0.002 \%$ \\
$\mathrm{Rb}$ & $0.014 \%$ \\
$\mathrm{Sr}$ & $0.0149 \%$ \\
$\mathrm{Y}$ & $0.0143 \%$ \\
$\mathrm{Sr}$ & $0.0107 \%$ \\
\hline
\end{tabular}

\section{Conclusion}

This research demonstrated facile silica extraction of mineral rock obtained from Kokap, Kulonprogo. Higher $\mathrm{NaOH}$ concentration and lower particle size resulted higher silica yield. The highest extracted silica yield in this experiment was $4.89 \mathrm{gr}$ at a concentration of $5 \mathrm{~N} \mathrm{NaOH}$ and 200 mesh. By employing this method, the small community in the village could utilize the mineral rocks to produce sodium silicate.

\section{Acknowledgment}

This research was funded by LPPM UPN "Veteran" Yogyakarta 2020 with reference number B/105/ UN.62/PT/VII/2020.

\section{References}

Chun J., and Lee, J.H., 2020, Recent Progress on the Development of Engineered Silica Particles Derived from Rice Husk. Sustainability. 12. 1-19.

Fernandes, I.K., Sanchez, F.A.L., Jurado, J.R., Kieling, A.G., Rocha, T.L.A.C., Moraes, C.A.M., Sousa, V.C., 2017, Physical, chemical and electric characterization of thermally treated rice husk ash and its potential application as ceramic raw material. Adv. Powder. Technol. 28 (4). 1228-1236.

Ilochonwu, C.E., Nwajagu, C.O., Onyenanu, I.U., Nwonye, E.I., 2015, Effect of Temperature in Extraction of High Purity Amorphous Silica from Rice Husk for Silicon Production. EDP Congress. 219-227.

Ishmah, S.N., Permana, M.D., Firdaus, M.L., 2020, Extraction of silica from Bengkulu beach sand using alkali fusion method. Journal of Science Education, 4(2). 1-5

Rais, D.A., Muhammad, A., Panggabean, C.M., Ningsih, D.W., Khumayroh, R., 2020, Identifikasi struktur bawah permukaan sebagai pengontrol sebaran mineralisasi di dusun plampang dan sangon, desa kalirejo, kecamatan kokap, kabupaten kulonprogo, daerah istimewa yogyakarta. Jurnal geocelebes. 4 (2). 93-101

Rimsza, J.M., Jones R.E., Criscenti, L.J., 2018, Interaction of $\mathrm{NaOH}$ solutions with silica surfaces. J. colloid interface sci. 516. 128-137.

Sempana, E., Marurung, P., Riyanto, A., 2018, Pengaruh Konsentrasi $\mathrm{NaOH}$ Pada Ekstrak Nanosilika Berbasis Batu Apung. Jurnal teori dan aplikasi fisika. 6 (2).

Zuwwana, I., Riza, M., Aprilia, S., 2021, The impact of solvent concentration on the characteristic of silica from rice husk ash using sol gel method. IOP conf. Ser. Materials science and engineering. 1087 